\title{
Evaluation of Metal Ions in Rice Samples: Extraction and Direct Determination by ICP OES
}

\author{
Andrea Oliveira, ${ }^{a}$ Nivaldo Baccan ${ }^{a, b}$ and Solange Cadore ${ }^{*, a}$ \\ ${ }^{a}$ Instituto de Química, Universidade Estadual de Campinas, CP 6154, 13083-970 Campinas-SP, Brazil \\ ${ }^{b}$ Faculdade de Paulínia, 13140-000 Paulínia-SP, Brazil
}

\begin{abstract}
Foi desenvolvido um método de extração de íons de metais presentes em amostras de arroz, usando solução amoniacal de EDTA (ácido etilenodiamino tetraacético), $\mathrm{pH} \geq 10$, como agente extrator, sob as seguintes condições otimizadas: 0,20 g de amostra de arroz e 5,00 mL da solução amoniacal de EDTA, com 5 min de tempo de exposição em ultrassom. Usando condições robustas de ICP OES (espectrometria de emissão atômica por plasma acoplado indutivamente), foi possível analisar a solução extraída, obtendo-se valores de recuperação acima de $90 \%$ para a maioria dos elementos estudados ( $\mathrm{P}, \mathrm{K}, \mathrm{Mg}, \mathrm{Ca}, \mathrm{Zn}, \mathrm{Mn}, \mathrm{Cu}$ e $\mathrm{Mo}$ ) com $\mathrm{RSD}<5 \%$. Os resultados mostraram concordância com aqueles obtidos por extração assistida por microondas e para o material de referência certificado de farinha de arroz (NIST SRM 1568a). Os limites de detecção do método ficaram no intervalo de $0,007 \mathrm{mg} \mathrm{kg}^{-1}(\mathrm{Mn})$ - 48,68 $\mathrm{mg} \mathrm{kg}^{-1}(\mathrm{~K})$, mostrando uma detectabilidade adequada para a determinação das espécies de interesse. A análise das diversas amostras indicou que o arroz brasileiro integral contém teores mais elevados dos constituintes estudados, seguido pelo arroz parboilizado e o arroz agulhinha.
\end{abstract}

A method for extraction of metal ions present in rice samples using ammoniacal EDTA solution, $\mathrm{pH} \geq 10$, as extractor agent is proposed under the following optimized conditions: $0.20 \mathrm{~g}$ of rice sample and $5.00 \mathrm{~mL}$ of ammoniacal EDTA (ethylenediaminetetraacetic acid) solution, with $5 \mathrm{~min}$ of ultrasound exposure time. Using robust ICP OES (inductively coupled plasma atomic emission spectrometry) conditions, direct analysis of the extraction solution was allowed, and the recovery values obtained were above $90 \%$ for most of the studied elements ( $\mathrm{P}, \mathrm{K}, \mathrm{Mg}, \mathrm{Ca}, \mathrm{Zn}, \mathrm{Mn}, \mathrm{Cu}$ and Mo) with RSD $<5 \%$. The results were in good agreement with those obtained by microwaveassisted extraction and for the reference material of rice flour (NIST SRM 1568a). The limits of detection of method were in the range of $0.007 \mathrm{mg} \mathrm{kg}^{-1}(\mathrm{Mn})-48.68 \mathrm{mg} \mathrm{kg}^{-1}(\mathrm{~K})$, showing adequate detectability for the determination of the analytes. The analysis of different samples indicated that Brazilian "integral" rice contains higher contents of the constituents studied, followed by "parboiled" rice, and the "agulhinha" rice a long and thin grain type.

Keywords: rice samples, ethylenediaminetetraacetic acid, elemental determination, ICP OES

\section{Introduction}

Rice (Oryza sativa L.), actually represents one of the most important foodstuffs in the world; it is the basic dietary product for more than a thousand millions of human beings. Approximately $90 \%$ of rice produced in all the world is cultivated and consumed at the Asia. However, the Latin America occupies the second place in production and the third place in relation of rice consumption. Within this context, Brazil is considered one of the biggest rice manufacturer, and its consumption is estimated about 74-76 kg per habitant per year. ${ }^{1}$ Despite of great national

*e-mail: cadore@iqm.unicamp.br consume, the knowledge about Brazilian rice nutritional composition, taking into account the identification of inorganic metals present in the rice samples, followed its quantification, is still deficient.

In order to improve the knowledge about Brazilian rice nutritional composition, in this study a simple treatment of sample was investigated, and the inorganic metals were determined by inductively coupled plasma atomic emission spectrometry (ICP OES).

It is important to mention that in the pretreatment sample step, the use of ultrasonic probes has been shown to be an interesting and efficient alternative to traditional sample treatment, improving the performance of several different applications of analytical chemistry, such as 
extraction of inorganic and organic compounds, slurry dispersion, homogenization and other applications. ${ }^{2}$ For many sample treatment applications, the samples were sonicated in an acidic medium, employing single acids (e.g., $\mathrm{HCl}, \mathrm{HNO}_{3}, \mathrm{HF}$ ), acid mixtures (e.g., $\mathrm{HCl}+\mathrm{HNO}_{3}$, $\mathrm{HNO}_{3}+\mathrm{HF}$ ) or acid mixed with an oxidizing agent (e.g., $\mathrm{H}_{2} \mathrm{O}_{2}$ ). In these cases, the importance of having both acidic medium as extractant and high intensity probe sonication is pointed out by some authors. ${ }^{3,4}$ Although many sample treatments employ an acidic medium, alkaline media have also led to the development of suitable sample preparation procedures, involving digestions, extractions or slurry formation before determination using spectroanalytical techniques. ${ }^{5}$ Thus, the use of alkaline medium in the sample treatment is a good alternative for some analytical tasks and provides fast and simple sample preparation approaches. Tetramethylammonium hydroxide (TMAH) is extensively used for this purpose, mainly for the digestion of biological and botanical samples. ${ }^{6-9}$ TMAH associated with ethylenediaminetetraacetic acid (EDTA) has also been studied for the alkaline digestion of botanical samples. The addition of EDTA improved the element recoveries in the digest supernatant, considering the excellent ability of this complexing agent to form complexes with many elements. In these alkaline procedures, the metal determination was generally performed by flame or electrothermal atomic absorption spectrometry (FAAS, ETAAS) ${ }^{10}$ or ICP OES..$^{11}$

Thus, in this work, an ammoniacal EDTA solution and an ultrasonic bath were employed in the sample treatment of food samples, being applied to different kind of Brazilian rice. The determination of several metallic species $(\mathrm{P}, \mathrm{K}$, $\mathrm{Mg}, \mathrm{Ca}, \mathrm{Zn}, \mathrm{Mn}, \mathrm{Fe}, \mathrm{Cu}$ and $\mathrm{Mo}$ ) in these rice samples was performed by ICP OES operating in robust plasma conditions, which facilitates the evaluation of the differences of nutritional composition between the rice species studied. The certified reference material of rice flour, NIST 1568a, was used to evaluate the accuracy of the proposed method.

\section{Experimental}

Instrumentation

For the total determination of elements, a microwave oven, model ETHOS 1 (Milestone, Sorisole, Italy), equipped with PTFE vessels was used for sample digestion.

The extractions of rice samples with EDTA solution were performed employing an ultrasound bath, Ultrasonic Cleaner (Unique, São Paulo, Brazil), model, USC 1400 operating at a frequency of $40 \mathrm{kHz}$ and with ultrasound power of $120 \mathrm{~W}$. The ultrasound exposure time of the samples was optimized at $5 \mathrm{~min}$.
The analytical measurements were made with a simultaneous Perkin-Elmer ICP OES, model Optima 3000DV (Norwalk, CT, USA), equipped with a peristaltic pump, a crossflow nebulizer coupled to a Ryton double pass spray chamber (Scott type) and a ceramic central torch tube injector with an internal diameter of $2.0 \mathrm{~mm}$. This instrument has a solid-state segmented array charge coupled device (SCD) detector and operates in radial and axial torch configurations. For the axial viewing mode, which was employed in this work, the cool plasma recombination area was striped off with a shear gas interface $\left(\mathrm{N}_{2}\right)$. The entire system is controlled with PE Winlab software. All measurements were performed in triplicate for the best evaluation of precision and accuracy of the method. The operational spectrometer conditions are presented in Table 1.

Table 1. Instrument operating conditions for the determination of metallic species in rice samples

\begin{tabular}{ll}
\hline Sample flow rate / $(\mathrm{mL} \mathrm{min}$ & -1 \\
Radio frequency power / W & 1.00 \\
Plasma argon flow rate / $\left(\mathrm{L} \mathrm{min}^{-1}\right)$ & 1350 \\
Auxiliary argon flow rate / $\left(\mathrm{L} \mathrm{min}^{-1}\right)$ & 0.50 \\
Nebulization flow rate / $\left(\mathrm{L} \mathrm{min}^{-1}\right)$ & 0.60 \\
Read delay / s & 30 \\
Intregation time / s (min.-max.) & $1-5$ \\
Replicates & 3 \\
Wavelenghts / nm & P I: 213.617; K I: 766.490; \\
& Mg II: 279.077; Mg II: 280.271 \\
& Ca II 317.933; Zn II: 213.857 \\
& Mn II 257.610; Fe II: 238.204 \\
& Cu I 324.752; Mo II: 202.031 \\
& Al I: 237.313 \\
& 2 points, except for K - 1 point \\
\hline
\end{tabular}

Solutions and reagents

Pure argon (99.996\%, White Martins, São Paulo, Brazil) was used. Analytical solutions (1000 $\mathrm{mg} \mathrm{L}^{-1}$ in $2 \% \mathrm{v} / \mathrm{v} \mathrm{HNO}_{3}$, Merck, Darmstadt, Germany) of each analyte were used to prepare multielemental calibration standards in $0.10 \mathrm{~mol} \mathrm{~L}^{-1}$ ammoniacal EDTA medium. All the glassware used was previously cleaned with diluted nitric acid (10\% v/v) and rinsed with deionized water (18.2 M $\Omega$ cm, Milli-Q Water Purification System Millipore, Bedford, USA).

The $0.10 \mathrm{~mol} \mathrm{~L}^{-1}$ of ammoniacal EDTA solution (Aldrich) was prepared by the dissolution of ethylenediaminetetraacetic acid EDTA, (29.225g) in $700 \mathrm{~mL}$ of deionized water. A $24 \%$ (v/v) ammonium hydroxide solution was added in order to obtain a $\mathrm{pH} c a .10$ EDTA solution. 
Then, the volume of the ammoniacal EDTA solution was filled to $1.00 \mathrm{~L}$ with deionized water. The EDTA ammoniacal solution were stored in polyethylene flasks and left under refrigeration at a temperature of about $4{ }^{\circ} \mathrm{C}$.

\section{Samples}

The rice samples correspond to three different kinds of Brazilian rice, being: "agulhinha" rice (AR), "parboiled" rice (PR) and "integral" rice (IR), all purchased in local supermarkets at Campinas City, São Paulo State, Brazil. These rice samples are slightly different, one from another, mainly due to their intrinsic properties such as genotype, as well as due to different treatments that were applied on the rice before packaging for sale.

\section{Procedure}

\section{Determination of total content assisted by microwave radiation}

The rice samples were first ground and then, digested in closed vessels in a microwave oven decomposition system according to the following procedure. Samples $(0.25 \mathrm{~g})$ were accurately weighed into a PTFE digestion vessel and then $4 \mathrm{~mL}$ of $65 \%(\mathrm{v} / \mathrm{v}) \mathrm{HNO}_{3}, 1 \mathrm{~mL} 30 \%(\mathrm{v} / \mathrm{v})$ $\mathrm{H}_{2} \mathrm{O}_{2}$ and $3 \mathrm{~mL}$ of Milli-Q water were added. The closed vessels were placed inside the microwave oven and the decomposition was carried out according to the program shown in Table 2. After that, the digests were left to cool and then the volumes were made up to $25 \mathrm{~mL}$ with Milli-Q water, followed by the quantifications of these elements by ICP OES.

\section{Optimization of experimental extraction conditions for metals in rice samples}

A $2^{3}$ factorial design, with central point, resulting in 27 experiments was done in order to find the best experimental conditions for the extraction of metallic species from the rice samples. For this purpose, the software employed was Statgraphics Plus 3.0, and the variables studied were: sample weight, volume of ammoniacal EDTA solution and time of ultrasound sample exposure, as described in Table 3. Further, the best extraction condition was applied in the reference material, NIST 1568a, for optimization of
Table 2. Microwave oven program for the decomposition of rice samples

\begin{tabular}{lccc}
\hline Step & time $/$ min & Power $/ \mathrm{W}$ & Temperature $/{ }^{\circ} \mathrm{C}$ \\
\hline 1 & 6 & 1000 & 80 \\
2 & 2 & 1000 & 80 \\
3 & 3 & 1000 & 120 \\
4 & 2 & 1000 & 120 \\
5 & 10 & 1000 & 180 \\
6 & 10 & 1000 & 180 \\
\hline
\end{tabular}

the instrumental parameters of ICP OES and also in the commercial rice samples.

\section{Extraction of elements with ammoniacal EDTA solution}

According to the $2^{3}$ factorial design, portions of rice samples ground were accurately weighed into polypropylene centrifuge tubes $(50 \mathrm{~mL}$ volume) and different volumes of $0.10 \mathrm{~mol} \mathrm{~L}^{-1}$ ammoniacal EDTA extractant solution were added. Then, the samples were sonicated at room temperature for different times at a frequency of $40 \mathrm{kHz}$ and with ultrasound power of $120 \mathrm{~W}$. After sonication, the samples were centrifuged for $10 \mathrm{~min}$ at $3600 \mathrm{rpm}$, and the supernatants were separated from insoluble residues and taken for analysis.

Optimization of instrumental conditions for extraction of metallic species in rice samples

For the study of robust plasma conditions, the ammoniacal EDTA solution was spiked with $5.00 \mathrm{mg} \mathrm{L}^{-1}$ of $\mathrm{Mg}$ standard solution and analyzed at different nebulization gas flow rates, (from 0.20 to $1.00 \mathrm{~L} \mathrm{~min}^{-1}$ ), and plasma power (from 1500 to $1000 \mathrm{~W}$ ). These parameters were analyzed separately and the selected instrumental conditions are shown in Table 1. Plasma robustness was calculated by dividing the Mg II by Mg I ammoniacal EDTA solution emission intensities. ${ }^{12}$ Using the optimized operational conditions, that are, plasma power of $1350 \mathrm{~W}$ and $0.60 \mathrm{~L} \mathrm{~min}^{-1}$ of nebulization flow rate, analysis of the certified reference material was carried out. The use of this certified material allowed the evaluation of matrix and spectral interferences, as well as to choose adequate wavelengths for the studied elements by optimizing the proposed method, leading to more accurate results.

Table 3. Values of the variables employed in the $2^{3}$ factorial design

\begin{tabular}{lccc}
\hline Parameter & Sample weight / g & Volume extracting solution / mL & Ultrasound time exposure / min \\
\hline Minimum level & 0.05 & 5.00 & 1 \\
Central point & 0.125 & 7.50 & 3 \\
Maximum level & 0.20 & 10.00 & 5 \\
\hline
\end{tabular}




\section{Results and Discussion}

\section{The plasma robustness optimization}

The optimization of the instrumental parameters in order to obtain a robust plasma has been studied by other researchers. ${ }^{12-14}$ The $\mathrm{Mg}$ II/Mg I ratio is a practical criterion to evaluate plasma robustness. The term robustness indicates how efficient is the energy transfer and the plasma response to change in atomization and excitation conditions due to the chemical composition of the aspirated sample. ${ }^{12}$ The robust conditions are effective to reduce matrix effects, mainly the interference caused by easily ionized elements, such as, $\mathrm{Na}, \mathrm{K}$ and $\mathrm{Ca}$ and also organic matter. ${ }^{15}$ Thus, to evaluate the plasma performance, experiments were carried out by applying a radio-frequency power of $1300 \mathrm{~W}$, and afterwards by adjusting the nebulizer gas flow rate in order to reach the highest $\mathrm{MgII} / \mathrm{MgI}$ ratio, as observed in Figure 1. The robustness was calculated by dividing the emission of the ionic line of $\mathrm{Mg}$ II $(280.270 \mathrm{~nm})$ by the atomic line of $\mathrm{Mg} \mathrm{I}(285.213 \mathrm{~nm}) .{ }^{12} \mathrm{~A} \mathrm{MgII} / \mathrm{MgI}$ ratio $\geq 10$ indicates that the plasma is operating in robust conditions.

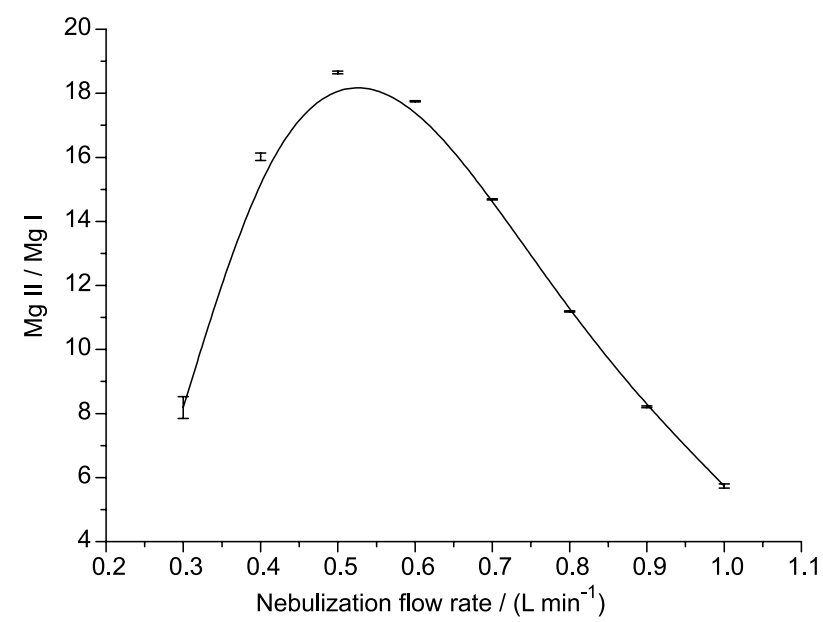

Figure 1. Effect of nebulization flow rate on the $\mathrm{Mg} \mathrm{II} / \mathrm{Mg}$ I ratio for ammoniacal EDTA solution. Operational conditions: power of $300 \mathrm{~W}$ and auxiliary gas flow $0.50 \mathrm{~L} \mathrm{~min}^{-1}$.

As can be seen in Figure 1, when 0.50 and $0.60 \mathrm{~L} \mathrm{~min}^{-1}$ nebulization flow rates were applied, the highest values for the $\mathrm{MgII} / \mathrm{MgI}$ ratio were reached. At a $0.50 \mathrm{~L} \mathrm{~min}^{-1}$ nebulization flow rate, the value obtained for the $\mathrm{MgII} / \mathrm{MgI}$ ratio was 18.65 , and the relative standard deviation (RSD) ca. $4 \%$. When the $0.60 \mathrm{~L} \mathrm{~min}^{-1}$ of nebulization flow rate was applied, the $\mathrm{MgII} / \mathrm{MgI}$ ratio was 17.75 and RSD obtained in this condition was RSD $<2 \%$. In this case, both nebulization flow rates are adequate for working under robust conditions, however, the value of $0.60 \mathrm{~L} \mathrm{~min}^{-1}$ was chosen, taking into account the lower values obtained for RSD. Furthermore, spectral interferences as well as matrix effects should be considered: organic matter or other concomitants can be co-extracted together with the metallic species of interest in the ammoniacal EDTA medium. This justifies the option for robust plasma in conditions of the lowest possible values of $\mathrm{RSD}$ in order to reduce such undesirable effects. In relation to plasma power, studies were also carried out varying it over the range from 1000 to $1500 \mathrm{~W}$ in order to choose the power that presents a $\mathrm{MgII} / \mathrm{MgI}$ ratio $\geq 10$.

Figure 2 shows that throughout the range of plasma power applied (from 1000 to $1500 \mathrm{~W}$ ), the $\mathrm{MgII} / \mathrm{MgI}$ ratios obtained are higher than 10, and the respective values of $\mathrm{RSD}<3 \%$. However, for power values below $1200 \mathrm{~W}$, such as 1100 and $1000 \mathrm{~W}$, the plasma generated was not stable. In fact, with these values of power the plasma extinguished when the nebulized sample was introduced into the plasma generated under these conditions, not being possible to quantify the analyte. Further, even if the plasma is not extinguished, in this case using $1200 \mathrm{~W}$ of applied power, the data repeatability is prejudiced, and values of $\mathrm{RSD} \geq 10 \%$ were obtained. This happens possibly due to matrix interference, taking into account that the sample is directly introduced into the plasma. Then, the instrumental operational conditions were established as $1350 \mathrm{~W}$ of plasma power and $0.60 \mathrm{~L} \mathrm{~min}^{-1}$ of nebulization flow rate, and the determination of elements extracted by the ammoniacal EDTA solution obtained with different experimental conditions were tested.

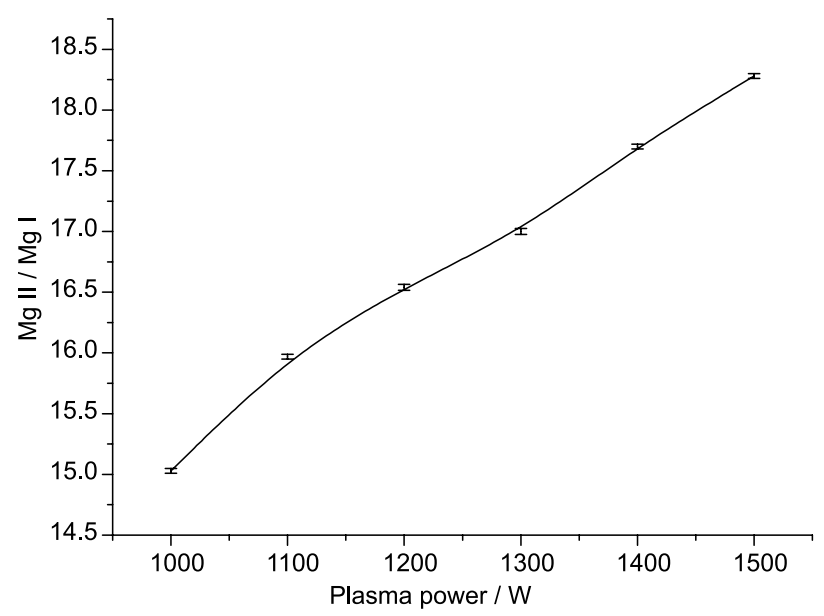

Figure 2. Effect of plasma power on the $\mathrm{Mg} \mathrm{II} / \mathrm{Mg}$ I ratio for ammoniacal EDTA solution. Operational conditions: nebulization flow rate of $0.60 \mathrm{~L} \mathrm{~min}^{-1}$ and auxiliary gas flow $0.50 \mathrm{~L} \mathrm{~min}^{-1}$.

The use of ammoniacal EDTA solution as extractor agent

The use of EDTA as an extracting agent for metals has been reported by some researchers. ${ }^{7-9}$ It is well known that the addition of EDTA improves element recoveries in 
the digest supernatant, considering the excellent ability of this reagent to form complexes with many elements. The values of formation constant $\left(\mathrm{K}_{\mathrm{f}}\right)$ for metal-EDTA are favorable for the most elements studied, such as [K-EDTA] 6.3; [Mg-EDTA] $4.9 \times 10^{8}$; [Ca-EDTA] $4.9 \times 10^{10}$; [ZnEDTA] $3.2 \times 10^{16} ;$ [Mn-EDTA] $7.4 \times 10^{13} ;$ [Fe(III)-EDTA] $1.3 \times 10^{25} ;$ [Cu-EDTA] $6.3 \times 10^{18}$ and [Al-EDTA] $2.0 \times 10^{16}$, respectively. ${ }^{16}$ Uchida et al. ${ }^{8}$ recommended the use of the EDTA diammonium salt, but this form was unavailable from the major chemical supplies. EDTA disodium salt and EDTA as acid were readily obtained. Filgueiras et al. ${ }^{7}$ employed the ammoniacal EDTA solution at $\mathrm{pH}>10$ for metal complexation in plant tissues and observed remarkable increases in metal solubilization efficiencies. EDTA form is very difficult to dissolve in water, but easily soluble in an ammoniacal solution. In this study, a $0.10 \mathrm{~mol} \mathrm{~L}^{-1}$ ammoniacal EDTA solution at $\mathrm{pH}>10$ was employed, considering at this $\mathrm{pH}$, the bonding sites of EDTA are totally free to form complexes with metals. Moreover, in this ammoniacal EDTA medium ( $\mathrm{pH}>10)$, the competition of $\mathrm{H}^{+}$ions for bonding sites of EDTA is reduced, allowing an effective complexation of analytes. The conditional formation constants $\left(\mathrm{K}_{\mathrm{f}^{\prime}}\right)$ for metal-EDTA at $\mathrm{pH}$ ca. 10 were calculated for most metallic species studied, and considering that the value of $\alpha_{\mathrm{Y} 4-}=0.36$ at $\mathrm{pH} 10$ then, $\mathrm{K}_{\mathrm{f}^{\prime}}$ can be estimated, being $\mathrm{K}_{\mathrm{f}^{\prime}}=\alpha_{\mathrm{Y} 4-} \times \mathrm{K}_{\mathrm{f}}$. The values obtained for the metal elements studied at $\mathrm{pH} 10$ were: [K-EDTA] 2.3; [Mg-EDTA] $1.8 \times 10^{8}$; [Ca-EDTA] $1.8 \times 10^{10} ;$ [Zn-EDTA] $1.2 \times 10^{16} ;$ [Mn-EDTA] $2.7 \times 10^{13}$; [Fe(III)-EDTA] $4.7 \times 10^{24}$; [Cd-EDTA] $1.0 \times 10^{16}$; [Cu-EDTA] $2.3 \times 10^{18}$ and [Al-EDTA] $7.2 \times 10^{15}$, being slightly different from the formation constants mentioned above since they are $\mathrm{pH}$ dependent. However the values of the conditional constants obtained at $\mathrm{pH} \geq 10$ indicate that metal-EDTA complexation is still favorable for the effective extraction of metals.

\section{Optimization of extracting conditions for metals in rice samples}

Considering the factorial design, a total of 27 experiments were done to establish the conditions for metal extraction. The best recovery percent values for most of the metallic species investigated were obtained under the following conditions (the compromise condition): $0.20 \mathrm{~g}$ of sample, $5.00 \mathrm{~mL}$ of ammoniacal EDTA solution and $5 \mathrm{~min}$ of ultrasound exposure, as verified in Figures $3 \mathrm{a}$ and $3 \mathrm{~b}$.

Figure 3 a shows that at $95 \%$ confidence level, the EDTA volume (B), the sample weight (A) and the interaction between these variables $(\mathrm{AB})$ are significant and, as verified in Figure $3 b$, the higher sample weight and extracting time (a)

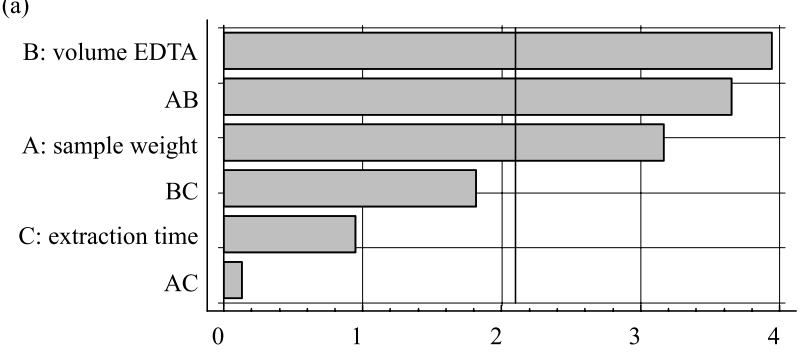

(b)

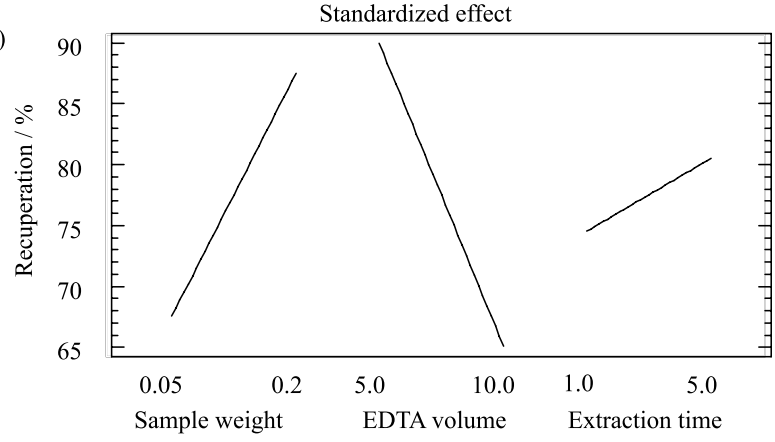

Figure 3. (a) Pareto plot for variables: (A) sample weight; (B) EDTA volume; (C) extraction time for optimization of metal extraction conditions. (b) Variable main effect plot, optimized extracting condition: (A) sample weight: $0.20 \mathrm{~g}$; (B) EDTA volume: $5.00 \mathrm{~mL}$; (C) extraction time: 5 min.

with lower EDTA volume provide adequate extracting conditions to reach the best recovery for most of the metallic species, except for Fe and $\mathrm{Al}$. The results obtained for the analyte concentrations in the certified reference material, NIST 1568a, employing extraction with ammoniacal EDTA solution is shown in Table 4.

The lower recovery obtained in this work for Fe has already been observed by Zhou et al. ${ }^{9}$ and by Filgueiras et al. ${ }^{7}$ and can be associated to the fact that both $\mathrm{Fe}$ and $\mathrm{Al}$ elements

Table 4. Concentrations and recovery values (in \%), for the analysis of the certified reference material, NIST 1568a rice flour, using the extraction conditions employed ( $\mathrm{n}=3, \pm$ standard deviation). Instrumental conditions: plasma power: $1350 \mathrm{~W}$, nebulization gas flow rate of $0.60 \mathrm{~L}$ $\min ^{-1}$, auxiliary gas flow of $0.50 \mathrm{~L} \mathrm{~min}^{-1}$

\begin{tabular}{lccc}
\hline Element & Certified value & Found value & Recovery / \% \\
\hline $\mathrm{P}$ & $0.153 \pm 0.008 \%$ & $0.111 \pm 0.009 \%$ & $72.7 \pm 0.6$ \\
$\mathrm{~K}$ & $0.128 \pm 0.0008 \%$ & $0.125 \pm 0.006 \%$ & $97.4 \pm 4.3$ \\
$\mathrm{Mg}$ & $0.056 \pm 0.002 \%$ & $0.054 \pm 0.0006 \%$ & $97.0 \pm 1.1$ \\
$\mathrm{Ca}$ & $0.012 \pm 0.0006 \%$ & $0.011 \pm 0.0002 \%$ & $91.1 \pm 2.1$ \\
$\mathrm{Zn}$ & $19.4 \pm 0.5 \mathrm{mg} \mathrm{kg}^{-1}$ & $18.5 \pm 0.8 \mathrm{mg} \mathrm{kg}^{-1}$ & $95.3 \pm 4.4$ \\
$\mathrm{Fe}$ & $7.4 \pm 0.9 \mathrm{mg} \mathrm{kg}^{-1}$ & $1.8 \pm 0.09 \mathrm{mg} \mathrm{kg}^{-1}$ & $23.9 \pm 1.3$ \\
$\mathrm{Mn}$ & $20.0 \pm 1.6 \mathrm{mg} \mathrm{kg}^{-1}$ & $19.1 \pm 0.7 \mathrm{mg} \mathrm{kg}^{-1}$ & $95.6 \pm 3.5$ \\
$\mathrm{Cu}$ & $2.4 \pm 0.3 \mathrm{mg} \mathrm{kg}^{-1}$ & $2.3 \pm 0.03 \mathrm{mg} \mathrm{kg}^{-1}$ & $96.8 \pm 1.4$ \\
$\mathrm{Mo}$ & $1.46 \pm 0.08 \mathrm{mg} \mathrm{kg}^{-1}$ & $1.41 \pm 0.02 \mathrm{mg} \mathrm{kg}^{-1}$ & $96.6 \pm 1.4$ \\
$\mathrm{Al}$ & $4.4 \pm 1.0 \mathrm{mg} \mathrm{kg}^{-1}$ & - & - \\
\hline
\end{tabular}


in presence of excess hydroxyl ions form the $\mathrm{Fe}(\mathrm{OH})_{3}$ and $\mathrm{Al}(\mathrm{OH})_{3}$ compounds, not dissolving in excess of ions $\mathrm{OH}^{-}$, remaining in the insoluble fraction. ${ }^{17}$ Additionally, the lower recovery can also be associated to the fact that Fe to proteins bond of the matrix produces a stable form, such as ferritin, considered crucial for Fe homeostasis. It consists of a multimeric spherical protein that is able to store up to 4,500 Fe atoms inside its central cavity in a non-toxic and bioavailable form, probably not being disturbed by this extraction procedure. ${ }^{18,19}$ In fact, the chemistry of Fe is more complex, as reviewed by Theil and Briat, ${ }^{20}$ which discuss plant ferritin that is one of the many dietary non-heme iron source in human nutrition. It is important to note that in all extracting experiments performed, a lower recovery for Fe was observed. In the case of aluminum, the extracting conditions established were not satisfactory considering its recovery. However, when the following extracting condition was used: $0.05 \mathrm{~g}$ of sample and $10 \mathrm{~mL}$ of ammoniacal EDTA solution; the recovery for $\mathrm{Al}$ was satisfactory $(102.1 \pm 2.7 \%)$, independent of ultrasound sample exposure time. For other elements studied, the recovery values were satisfactory. In general, the range of values obtained was about $91-97 \%$, except for $\mathrm{P}$.

\section{Figures of merit}

The limits of detection (LOD) and quantification (LOQ) were calculated as described by Thomsen et al.:21 $\mathrm{LOD}=(3 \times \mathrm{RSD} \times \mathrm{BEC}) / 100$, and considering that the $\mathrm{LOQ}=(10 \times \mathrm{RSD} \times \mathrm{BEC}) / 100$. In these expressions, RSD corresponds to the relative standard deviation for 10 measurements of the blank and BEC corresponds to the background equivalent concentration, which was experimentally determined under the optimized conditions. The calculated values for LOD and LOQ in $\mathrm{mg} \mathrm{L}^{-1}$ (instrumental figures of merit) were converted in $\mathrm{mg} \mathrm{kg}^{-1}$ (figures of merit of the proposed method) considering the sample dilution used, and are presented in Table 5.

Considering the values presented in Table 5 and the range of concentration of the analytes present in rice samples, for macro-constituents $\mathrm{P}(0.06-0.2 \%)$, $\mathrm{K}$ (0.04-0.1\%), Mg (0.01-0.1\%), Ca (0.003-0.007\%), and for micro-constituents $\mathrm{Zn}$ (7.3-14 $\left.\mathrm{mg} \mathrm{kg}^{-1}\right)$, Mn (4.6-17 $\mathrm{mg} \mathrm{kg}^{-1}$ ) and $\mathrm{Cu}$ (ca. $2.0 \mathrm{mg} \mathrm{kg}^{-1}$ ), it is possible to note that the proposed method has adequate detectability for the determination of these elements in rice samples.

\section{Analysis of rice samples}

The analysis of three different kinds of rice samples was carried out and the concentrations obtained are presented in
Table 5. Limits of detection (LOD) and quantification (LOQ) of method for the determination of metallic species in rice samples in ammoniacal EDTA solution

\begin{tabular}{lcc}
\hline Metallic species $(\lambda / \mathrm{nm})$ & LOD / $\left(\mathrm{mg} \mathrm{kg}^{-1}\right)$ & LOQ / $\left(\mathrm{mg} \mathrm{kg}^{-1}\right)$ \\
\hline P I 213.617 & 1.68 & 5.60 \\
K I 766.490 & 48.68 & 162.25 \\
Mg II 279.077 & 0.13 & 0.42 \\
Ca II 317.933 & 0.04 & 0.14 \\
Fe II 238.204 & 0.03 & 0.09 \\
Zn I 213.857 & 0.05 & 0.18 \\
Mn II 257.610 & 0.007 & 0.02 \\
Cu I 324.752 & 0.06 & 0.20 \\
Mo II 202.031 & 0.14 & 0.46 \\
Al I 237.313 & 0.81 & 2.71 \\
\hline
\end{tabular}

Table 6. The microwave-assisted digestion in closed vessels was used for comparison, and the values of concentration for the elements are reported.

As can be observed in Table 6, the values of concentration found for most of the elements are in agreement when comparing both sample treatment procedures employed, except for Fe. With microwave digestion, the recoveries for $\mathrm{Fe}$ in the samples of rice are higher than the values obtained with the EDTA extraction. Mo was not detected in these samples, probably because their concentrations are lower than LOD. The results obtained indicated that "integral" rice contains the highest content of the elements studied possibly due to the way this rice was manufactured. Thus, as can be observed, the proposed method is suitable for the determination of some inorganic elements present in rice. It is not necessary a laborious sample pretreatment, when compared to the acidic digestion, being commonly used for total determination of inorganic elements in food. Further, the direct introduction of the sample is also advantageous and, associated with robust plasma condition, the method is an efficient and fast analytical technique for detection of these analytes. Due to relative simplicity of the proposed method, it can be applied in routine analyses. In this kind of analysis, the reliable, simplicity and effectiveness are taking into account due to higher number of sample analyzed in a short time is required. Comparing the results from the proposed method and those obtained with acidic digestion, very close values were observed for the most of elements analyzed, except for the Fe, once this element is intrinsically bounded with the matrix. In this case, the ammoniacal EDTA solution is not an efficient extractor agent, such as acidic digestion. 
Table 6. Concentrations obtained for solubilization of inorganic species from rice samples employing microwave-assisted digestion and ammoniacal EDTA solution with ultrasound ( $\mathrm{n}=3, \pm$ standard deviation)

\begin{tabular}{|c|c|c|c|}
\hline Element & $\begin{array}{l}\text { Microwave } \\
\text { digestion }\end{array}$ & $\begin{array}{c}\text { EDTA } \\
\text { (ultrasound bath) }\end{array}$ & $\begin{array}{c}\text { Difference / } \\
\%\end{array}$ \\
\hline \multicolumn{4}{|c|}{ "Agulhinha" Rice } \\
\hline $\mathrm{P}$ & $0.064 \pm 0.004 \%$ & $0.058 \pm 0.002 \%$ & -9.4 \\
\hline $\mathrm{K}$ & $0.039 \pm 0.003 \%$ & $0.039 \pm 0.001 \%$ & 0.0 \\
\hline $\mathrm{Mg}$ & $0.013 \pm 0.001 \%$ & $0.014 \pm 0.00 \%$ & +7.7 \\
\hline $\mathrm{Ca}$ & $0.005 \pm 0.0001 \%$ & $0.005 \pm 0.0001 \%$ & 0.0 \\
\hline $\mathrm{Fe}$ & $2.8 \pm 0.06 \mathrm{mg} \mathrm{kg}^{-1}$ & $0.6 \pm 0.07 \mathrm{mg} \mathrm{kg}^{-1}$ & -78.6 \\
\hline $\mathrm{Zn}$ & $12.3 \pm 0.6 \mathrm{mg} \mathrm{kg}^{-1}$ & $11.4 \pm 0.6 \mathrm{mg} \mathrm{kg}^{-1}$ & -7.3 \\
\hline $\mathrm{Mn}$ & $14.5 \pm 0.3 \mathrm{mg} \mathrm{kg}^{-1}$ & $13.7 \pm 0.6 \mathrm{mg} \mathrm{kg}^{-1}$ & -5.5 \\
\hline $\mathrm{Cu}$ & $2.7 \pm 0.09 \mathrm{mg} \mathrm{kg}^{-1}$ & $2.7 \pm 0.08 \mathrm{mg} \mathrm{kg}^{-1}$ & 0.0 \\
\hline Mo & $<0.14$ & $<0.14$ & \\
\hline \multicolumn{4}{|c|}{ "Parboiled" Rice } \\
\hline $\mathrm{P}$ & $0.138 \pm 0.004 \%$ & $0.120 \pm 0.005 \%$ & -13 \\
\hline $\mathrm{K}$ & $0.116 \pm 0.005 \%$ & $0.121 \pm 0.004 \%$ & +4.3 \\
\hline $\mathrm{Mg}$ & $0.034 \pm 0.002 \%$ & $0.031 \pm 0.002 \%$ & -8.8 \\
\hline $\mathrm{Ca}$ & $0.003 \pm 0.0002 \%$ & $0.003 \pm 0.0001 \%$ & 0.0 \\
\hline $\mathrm{Fe}$ & $8.4 \pm 0.7 \mathrm{mg} \mathrm{kg}^{-1}$ & $1.8 \pm 0.03 \mathrm{mg} \mathrm{kg}^{-1}$ & -78.6 \\
\hline $\mathrm{Zn}$ & $7.8 \pm 0.3 \mathrm{mg} \mathrm{kg}^{-1}$ & $7.3 \pm 0.5 \mathrm{mg} \mathrm{kg}^{-1}$ & -6.4 \\
\hline $\mathrm{Mn}$ & $5.0 \pm 0.2 \mathrm{mg} \mathrm{kg}^{-1}$ & $4.6 \pm 0.3 \mathrm{mg} \mathrm{kg}^{-1}$ & -8.0 \\
\hline $\mathrm{Cu}$ & $2.2 \pm 0.08 \mathrm{mg} \mathrm{kg}^{-1}$ & $2.5 \pm 0.03 \mathrm{mg} \mathrm{kg}^{-1}$ & +13.6 \\
\hline Mo & $<0.14$ & $<0.14$ & \\
\hline \multicolumn{4}{|c|}{ "Integral" Rice } \\
\hline$P$ & $0.255 \pm 0.002 \%$ & $0.221 \pm 0.007 \%$ & -13.3 \\
\hline $\mathrm{K}$ & $0.149 \pm 0.005 \%$ & $0.158 \pm 0.002 \%$ & +6.0 \\
\hline $\mathrm{Mg}$ & $0.108 \pm 0.005 \%$ & $0.099 \pm 0.008 \%$ & -8.3 \\
\hline $\mathrm{Ca}$ & $0.008 \pm 0.0006 \%$ & $0.007 \pm 0.0002 \%$ & -12.5 \\
\hline $\mathrm{Fe}$ & $9.5 \pm 0.5 \mathrm{mg} \mathrm{kg}^{-1}$ & $6.4 \pm 0.3 \mathrm{mg} \mathrm{kg}^{-1}$ & -32.6 \\
\hline $\mathrm{Zn}$ & $15.9 \pm 0.5 \mathrm{mg} \mathrm{kg}^{-1}$ & $13.9 \pm 0.6 \mathrm{mg} \mathrm{kg}^{-1}$ & -12.6 \\
\hline Mn & $19.0 \pm 0.8 \mathrm{mg} \mathrm{kg}^{-1}$ & $17.3 \pm 0.9 \mathrm{mg} \mathrm{kg}^{-1}$ & -8.9 \\
\hline $\mathrm{Cu}$ & $2.1 \pm 0.06 \mathrm{mg} \mathrm{kg}^{-1}$ & $2.0 \pm 0.03 \mathrm{mg} \mathrm{kg}^{-1}$ & -4.8 \\
\hline Mo & $<0.14$ & $<0.14$ & \\
\hline
\end{tabular}

\section{Conclusions}

The study of extraction conditions employing ammoniacal EDTA solution associated with ultrasound gave satisfactory results for most of elements studied in three different types of rice samples. In this study, the capacity of EDTA to form complexes with the metals present in the rice samples was evaluated without need for complete digestion of the sample. The plasma operating in a robust condition was efficient, contributing to an effective control of the nutritional composition of different types of rice. The elements present in the rice samples can be monitored by this method to evaluate both the essentiality and toxicity of these elements, considering human health. For this purpose, the ease of direct introduction of the sample to the ICP OES equipment is an advantage in comparison to acidic digestion methods.

\section{Acknowledgments}

The authors are grateful to Conselho Nacional de Desenvolvimento Científico e Tecnológico (CNPq), Fundação de Amparo à Pesquisa do Estado de São Paulo (FAPESP) and Instituto Nacional de Ciências e Tecnologias Analíticas Avançadas (INCTAA) for financial support. The authors would also like to thank Prof. Dr. Carol Collins for her assistance with the English language.

\section{References}

1. Embrapa Clima Temperado; Sistemas de Produção 3, Pelotas, RS, Brasil, 2005, http://sistemasdeproducao.cnptia.embrapa.br accessed in October 2011.

2. Nascentes, C. C.; Korn, M.; Sousa, C. S.; Arruda, M. A. Z.; J. Braz. Chem. Soc. 2001, 12, 57.

3. Silva, R. G. L.; Willie, S. N.; Sturgeon, R. E.; Santelli, R. E.; Sella, S. M.; Analyst 1999, 124, 1843.

4. Pontes, F. V. M.; Mendes, B. A. D.; de Souza, E. M. F.; da Silva, L. I. D.; Carneiro, M. C.; Monteiro, M. I. C.; de Almeida, M. D.; Neto, A. A.; Vaitsman, D. S.; Anal. Chim. Acta 2010, 659, 55.

5. Nóbrega, J. A.; Santos, M. C.; Sousa, R. A.; Cadore, S.; Barnes, R. M.; Tatro, M.; Spectrochim. Acta, Part B 2006, 61, 465.

6. Costa, L. M.; Gouveia, S. T.; Nóbrega, J. A.; Anal. Sci. 2002, $18,313$.

7. Filgueiras, A. V.; Lavilla, I.; Bendicho, C.; Fresen. J. Anal. Chem. 2001, 369, 451.

8. Uchida, T.; Isoyama, H.; Yamada, K.; Oguchi, K.; Nakagawa, G.; Anal. Chim. Acta 1992, 256, 277.

9. Zhou, C. Y.; Wong, M. K.; Koh, L. L.; Wee, Y. C.; Talanta 1996, 43, 1061.

10. da Silva, J. B. B.; Borges, D. L. G.; Andreia, M.; da Veiga, M. S.; Curtius, A. J.; Welz, B.; Talanta 2003, 60, 977.

11. Ribeiro, A. S.; Moretto, A. L.; Arruda, M. A. Z.; Cadore, S.; Mikrochim. Acta 2003, 141, 149.

12. Mermet, J. M.; Anal. Chim. Acta 1991, 250, 85.

13. Silva, F. V.; Trevizan, L. C.; Silva, C. S.; Nogueira, A. R. A.; Nóbrega, J. A.; Spectrochim. Acta, Part B 2002, 57, 1905.

14. Silva, J. C. J.; Santos, D. M.; Cadore, S.; Nóbrega, J. A.; Baccan, N.; Microchem. J. 2004, 77, 185.

15. Brenner, I. B.; Zander, A.; Cole, M.; Wiseman, A.; J. Anal. At. Spectrom. 1997, 12, 897.

16. Skoog, D. A.; West, D. M.; Holler, F. J.; Fundamentals of Analytical Chemistry, $7^{\text {th }}$ ed.; Saunders College Publishing: New York, 1996. 
17. Lee, J. D.; Química Inorgânica não tão Concisa, $4^{\mathrm{a}}$ ed., Edgar Blücher: Rio de Janeiro, RJ, Brasil, 1991.

18. Silveira, V. C.; Fadanelli, C.; Sperotto, R. A.; Stein, R. J.; Basso, L. A.; Santos, D. S.; Vaz Junior, I. S.; Dias, J. F.; Fett, J. P.; Sci. Agric. 2009, 66, 549.

19. Theil, E. C.; Matzapetakis, M.; Liu, X.; J. Biol. Inorg. Chem. 2006, 11,803 .
20. Theil, E. C.; Briat, J. F.; Int. Food Pol. Res. Inst. Int. Cent. Trop. Agric. 2004. 1-13.

21. Thomsen, V.; Roberts, G.; Burgess, K.; Spectroscopy 2000, 15, 33.

Submitted: September 24, 2011

Published online: April 3, 2012

FAPESP has sponsored the publication of this article. 